\title{
Impact of Burning, Cropping and Microbial Inoculation on Soil Alpha- Proteobacterial Community Composition in Shifting Cultivation Cycle
}

\author{
Carolyn Zothansiami*
}

\author{
School of Natural Resource Management, College of Post Graduate Studies, Central \\ Agricultural University-Imphal, Umiam, 796 3103, Meghalaya, India
}

*Corresponding author

\section{Keywords}

Jhum, Microbial community, Alpha proteobacterial communities

Article Info

Accepted: 04 June 2019 Available Online: 10 July 2019

\section{A B S T R A C T}

Terrestrial ecosystems consist of above- and below-ground components that interact to influence community- and ecosystem-level processes and properties. Soils act as the most important medium for linking the above and below ground community which are of very sensitive to any external disturbances. To study the effect of disturbances and also the influence of crop to soil microbial community which are an indicators of biological soil processes a short cycle of jhum practices from Mizoram was selected and study in a microcosm experiment. The experiment was carried out in four (4) set where there was burnt soil which consist of rice crop and without rice crop and unburnt soil where there was rice crop and without rice crop. The study reveals that the soil bacterial community composition altered significantly due to burning of slashed biomass on soil surface. The introduction of rice crop also altered the bacterial community composition in burnt/unburnt which shows a distinct cluster within the soil type. The Alpha proteobacterial communities of burnt and unburnt without rice crop clustered together and distinctly separated from the clusters of burnt and unburnt soil with rice crop at 45 days of rice growth and at 90 days of rice growth the impact of rice crop.

\section{Introduction}

Terrestrial ecosystems consist of above- and below-ground components that interact to influence community- and ecosystem-level processes and properties. Soils act as the most important medium for these linkages (Bradgett, 2008; Suleiman et al., 2013). Soils are known to house the most diverse microbial communities that are responsible for innumerable soil processes. An array of soil enzymes produced by the diverse groups of microbes act as the drivers of majority These above-ground vegetations and below-ground biota linkages get disturbed due to anthropogenic activities which thus then leads to modifications of soil microbial communities, threatening of their diversity and result in losses of functions when specific structural patterns or regulation mechanisms 
are lost (Lavelle, 1997; da Jesus et al., 2009; Alguacil et al., 2014; Köhl et al., 2014). Plantmicrobe interactions in the rhizosphere are responsible for a number of soil processes that include carbon sequestration, ecosystem services, and nutrient recycling. The composition and quantity of microbes in the soil influence the ability of plants to obtain nitrogen and other nutrients (Hoorman, 2011). Soil microbial communities depend on plant root exudates for carbon and nitrogen sources, thus shift in vegetation is thought to influence soil microbial community structure. Plant species composition is one of the major contributing factors for shaping up the microbial community (Liliensiek et al., 2012). The native soil communities play fundamental roles in ecosystem properties and processes (Wolfe and Kilrinomos, 2005). The predominant farming practice i.e. jhumming (a common farming practice in the Northeastern Hill States of India) is known for destruction of the above-ground biomass through slash and burn activities. Thus, the disruption of the linkages between above- and below ground biota communities may have altered the natural functioning mechanisms of soil microbial communities leading to detrimental impact on soil processes and overall ecological imbalances in soils of jhum agroecosystems

\section{Materials and Methods}

\section{Description of the sampling site}

Mizoram is one among the North Eastern states where shifting cultivation is practices extensively. Due to the increase in population the area for agricultural land has decrease and thus lead to a pressure on land which results in reduces of jhum cycle into 3-5 years from 1020 years in many areas. Keeping this in view five (5) years jhum cycles from Muallungthu village Aizawl district Mizoram was selected as a study area which lies between $23^{0} 36.279^{\prime}$
$\mathrm{N}$ latitude and $92^{\circ} 42.909^{\prime} \mathrm{E}$ Longitude at altitude of 841-857 m.

\section{Soil sampling and processing for microcosm experiment}

From the identified 5 years jhum cycle before slashing the biomass soils sample at a depth of 0 to $15 \mathrm{~cm}$ of was collected which represent the unburnt soil and the next day after burning but before the sowing the seed soil samples was collected at a same depth which represent the burn soils. The collected soils from burnt and unburnt situations were allowed to pass through $2 \mathrm{~mm}$ sieve separately and removed all visible fine roots and other organic debris and keep it ready for the microcosm experiment.

\section{Microcosm experiment}

To study the Impact of slash-burning and plant species on soil microbial community and processes in Jhum agro-ecosystem microcosm experiment was carried out set under poly house at the Experimental Farm of the College of Post Graduate Studies, Umiam, Meghalaya. A series of pots were arranged in 4 groups. In two groups i.e burnt and unburnt soil jhum rice was grown where in the other 2 groups no crop was grown. The bulk density of the pot soil was adjusted based on weight by volume basis to mimic the bulk density in field situations. Only after the pot soil mimic bulk density of the field situation functional microbial groups were inoculated followed by sowing of upland hill rice variety (Khawlian buh). Soil moisture in the pot was maintained at field capacity throughout the experimental period

\section{Preparation of synthetic microbial community and fungal inocula}

Each group of pot experiment was treated with different bacterial functional groups and a 
synthetic fungal community. Three functional bacterial groups are: (1) $\mathrm{N}_{2^{-}}$fixers, (2) Phosphate Solubilising Bacteria (PSB), and (3) Cellulose Degrading Bacteria (CDB). All together six (6) treatment combinations was imposed viz. T1: 5 strains $\mathrm{PSB}+5$ strains synthetic fungal community, T2: 5 strains $\mathrm{N}_{2-}$ fixers +5 strains synthetic fungal community, T3: 5 strains $\mathrm{CDB}+5$ strains synthetic fungal community, T4: 5 strains each of PSB $+\mathrm{N}_{2^{-}}$ fixers $+\mathrm{CDB}+5$ strains synthetic fungal community, T5: No bacteria +5 strains synthetic fungal community and T6: No inoculation. Fungi was isolated from the jhum soil using Rose Bengal agar medium ( $\mathrm{pH} 4.5$ ) supplemented with streptomycin sulphate (Subba Rao, 1999). This isolated fungi was used in the microcosm experiment as one of the treatment

\section{Production of microbial consortium}

Well decomposed compost material was air dried, grinded and sieved through $1 \mathrm{~mm}$ sieve then packed in an auto-clavable plastic bags, air-tighten with a rubber band and performed tyndallisation process of sterilization in order to avoid contamination from unwanted microbes. Five efficient functional bacteria from each 3 groups were grown as a pure culture in $5 \mathrm{ml}$ of nutrient broth (NB) and were incubated $\left(30^{0} \mathrm{c} \pm 0.5\right.$ at $\left.160 \mathrm{rpm}\right)$ for 22 hrs till attainment of maximum viable cells. One milliliter of mother culture from each bacterial group was transferred aseptically in a series of $150 \mathrm{ml} \mathrm{NB}$ and incubated in an environmental shaker cum incubator at $30^{\circ} \mathrm{c} \pm 0.5$ at $160 \mathrm{rpm}$ for $22 \mathrm{hrs}$. After incubation $150 \mathrm{ml}$ broth of each functional microbial groups $(150 \mathrm{ml} X 5=750 \mathrm{ml}$ in $1000 \mathrm{~g}$ of compost for each group i.e. $\mathrm{C}, \mathrm{N}$ and $\mathrm{P})$ was mixed uniformly using aseptically.

Five efficient synthetic fungal communities was grown as a pure culture in $100 \mathrm{ml}$ of Rose Bengal Agar Media and were incubated $\left(30^{0} \mathrm{c} \pm 0.5\right)$ for 5 days till attainment of maximum viable cells. The full grown sporeswas grind aseptically by using autoclaved mortal and pestal after this it was aseptically mixed with 1000 gm sterile soil

\section{Analysis of soil basic properties}

Soil physico-chemical properties were determined as per the standard procedures described in Page et al., (1982). In brief, soil $\mathrm{pH}$ was measured in 1: 2.5 soil: $\mathrm{H}_{2} \mathrm{O}$ suspension, Bulk density (BD) was determined by Keen (Rackzowski) box technique. Electrical conductivity (EC) was measured in 1: 5 soil: $\mathrm{H}_{2} \mathrm{O}$ suspensions using a standard Conductivity Meter (EuTech, Merck) with 2 cell constants and calibrated using standard solutions. Soil organic carbon (SOC) was determination by the potassium dichromate wet oxidation method. Soil available nitrogen (Avl.N) by following alkaline permanganate oxidation method and soil available phosphorus (Avl.P) was determined by the stannous chloride blue colour meter where the soil available potassium (Avl.K) was determined by the neutral normal ammonium acetate extraction and flame photometry method.

\section{Extraction of soil DNA}

Soil DNA was extracted based on the principle of in-situ lysis DNA extraction method. using the Power Soil ${ }^{\mathrm{TM}}$ DNA isolation kit (MoBio Laboratories Inc., Carlsbad, USA)

Quality in terms of molecular size of extracted soil DNA was determined by electrophoresis of $5 \mu \mathrm{l}$ of DNA aliquot in an agarose gel $\left(0.8 \% \mathrm{~W} \mathrm{v}^{-1}\right.$ containing Gel-Red fluorochrom stain with a working strength of $0.06 \mathrm{X}$, Biotium, USA) using a mini gel electrophoresis assembly (HU10, Sci-plas, Hongkong). Gels were visualized and images 
captured using gel documentation system (BioRad, CA, USA). EcoRI/HindIII-cut bacteriophage lambda DNA molecular size marker (250 ng; Invitrogen, UK) was included on gels as standard and the amount of DNA in samples was determined by comparing the fluorescence of genomic DNA bands to that of ladder and was expressed as $\mu \mathrm{g} \mathrm{g}^{-1}$ dry wt of soil (Zhou et al., 1996). The absorption spectrum of DNA extracts $(230-280 \mathrm{~nm})$ was determined using a Nano-drop ${ }^{\circledR} \quad 2000$ spectrophotometer (Thermo Scientific, USA).

A decrease in absorption ratio at 260/230 and $260 / 280 \mathrm{~nm}$ was used as indicator of humic acid, polysaccharide and protein impurities (Stach et al., 2001; Thakuria et al., 2008).

PCR amplification of bacterial 16S rRNA genes from soil DNA

Extracted soil DNA was amplified in a Gradient Master Cycler 5331 (Eppendorf Make, Germany) with primer pair (27f and 1492r) specific to bacterial domain (Lane et al., 1991).

This primer pair is specific to $16 \mathrm{~S}$ rRNA genes of the bacterial domain and yields amplified product size of approximate 1465 bp.

\section{PCR amplification for $\alpha$-proteobacteria}

The extracted DNA was amplified in thermo scientific thermocycler using a primer pair of $203 \mathrm{f} \alpha$ and 1494r (203f $\alpha: 5^{\prime}$ CCGCATACGCCCTACGGGGGAAAGATT TAT and 1494r: 5'CTACGGTCTAGCCTTGTTACGAC). The amplified template was re-amplified using a primer pairs of 984fgcand1378r (984fgc:5'CGCCCGGGGCGCGCCCCGGGC GGGGCGGGGGCACGGGGGGAACGCGA AGAACCTTAC and 1378r 5'GCGGTGTGTACAAGGCCCGGGAACG).
Denaturing gradient gel electrophoresis (DGGE) fingerprinting of bacterial community composition

Denaturing gradient gel electrophoresis (DGGE) was performed using Ingeny PhorU2 system (Ingeny International BV, The Netherlands). The stained gel was visualized and image was captured using gel documentation system (BioRad, CA, USA).

\section{Statistical Analysis}

The statistical analysis was done using PRIMER v6.1.9 software.

\section{Results and Discussion}

Physico-chemical properties (BD, pH, EC, SOC, Avl N, Avl P and Avl K) of soils under burnt and unburnt conditions is presented in Table 1. Values of BD, pH, EC, Avl P and Avl $\mathrm{K}$ in burnt soil were significantly higher relative to their values in unburnt soil under 5 year jhum cycle. On the other hand the contents of SOC and Avl $\mathrm{N}$ under burnt soil were significantly lower relative to their values in unburnt soil.

\section{Soil bacterial community at $\mathbf{1 0}$ days of rice growth}

The PCR-DGGE fingerprint revealing the bacterial community composition in burnt and unburnt soils in presence or absence of rice crops at 10 days of rice plant growth is depicted in Figure 1 The number and the relative intensity of bands are clearly visible in the PCR-DGGE fingerprint. The MDS plot developed on binary matrix of PCR-DGGE fingerprint showed distinct clustering between burnt and unburnt soils (Fig. 2). The bacterial community of burnt soil or unburnt soil clustered separately according to the absence and presence of rice crop at $80 \%$ similarity level and the separation among clusters were 
positively differ from each other as confirmed by Hierarchical cluster analysis (incorporating SIMPROF test at $95 \%$ confidence limit) (Fig. 3). Interestingly, the clusters representing bacterial communities of burnt soil distinctly separated out from the clusters of unburnt soil irrespective of rice crop present or absent (Fig. 2). Within burnt or unburnt soil conditions, the two distinct clusters were represented by the bacterial communities in presence or absence of rice crop. Though there were variations in bacterial community compositions among the treatments, these treatment induced variations couldn't mask the effect of burning and cropping. The stronger factor of variability in shaping the soil bacterial community composition was found to be in the order burning > cropping > microbial inoculation treatment.

\section{Soil bacterial (alpha-proteobacteria) community at 45 days of rice growth}

The PCR-DGGE fingerprint revealing the alpha-proteobacteria community composition at 45 days of rice plant growth is depicted in (Fig. 4). The number and the relative intensity of bands are clearly visible in the PCR-DGGE fingerprint. The MDS plot developed on binary matrix of PCR-DGGE fingerprint showed distinct clustering between burnt and unburnt soils (Fig. 5). The bacterial community of burnt soil or unburnt soil clustered separately according to the presence and absence of rice crop at $72 \%$ similarity level and the separation among clusters were significantly different from each other as confirmed by Hierarchical cluster analysis (incorporating SIMPROF test at 95\% confidence limit) (Fig. 6). Interestingly, the clusters representing bacterial communities of burnt soil distinctly separated out from the clusters of unburnt soil according to the present or absent of rice crop (Fig. 5). Within burnt or unburnt soil conditions, the two distinct clusters were represented by the bacterial communities in presence or absence of rice crop. Though there were variations in bacterial community compositions among the treatments, these treatment induced variations couldn't mask the effect of burning and cropping. The stronger factor of variability in shaping the soil alpha-proteobacterial community composition was found to be in the order burning > cropping > microbial inoculation treatment (Fig. 7).

\section{Soil bacterial (alpha-proteobacteria) community at 90 days of rice growth}

The PCR-DGGE fingerprint revealing the alpha-proteobacteria community composition at 90 days of rice plant growth is depicted in (Fig. 8). The number and the relative intensity of bands are clearly visible in the PCR-DGGE fingerprint. The MDS plot developed on binary matrix of PCR-DGGE fingerprint showed distinct clustering between burnt and unburnt soils (Fig. 9). The bacterial community of burnt soil or unburnt soil clustered separately according to the presence or absence of rice crop at $58 \%$ similarity level and the separation among clusters were significantly different from each other as confirmed by Hierarchical cluster analysis (incorporating SIMPROF test at $95 \%$ confidence limit) (Fig. 10).

Interestingly, the clusters representing bacterial communities of burnt soil distinctly separated out from the clusters of unburnt soil according to the present or absent of rice crop (Fig. 9). Within burnt or unburnt soil conditions, the two distinct clusters were represented by the bacterial communities in presence or absence of rice crop. Though there were variations in bacterial community compositions among the treatments, these treatment induced variations couldn't mask the effect of burning and cropping. The stronger factor of variability in shaping the soil alpha-proteobacterial community 
composition at 90 days was found to be in the order burning > cropping > microbial inoculation treatment

In slash and burn agriculture burning activities play a major role in altering soil microbial community. Soil microbes are sensitive to fire. The microbial community in soil can be affected by fire, land use and change in plant species which are the main component in shifting cultivation. Abiotic and biotic factors hampers the soil productivity, quality and its constancy (Girvan et al., 2005). In our studies burning become the strongest factor the stronger in shaping the soil bacterial communities at 10 days of rice plant growth and alpha-proteobacterial community composition at 45 and 90 days of rice plant growth followed by cropping and microbial inoculation treatment. A structural difference of soil microbial community due to fire was also reported by (Hamman et al., 2007; Xiang et al., 2014). The aboveground vegetation affects the size, abundance, diversity, composition and activity of microbial community in soils (Nusslein and Tiedji, 1999, da Jesus et al., 2009; Xue et al., 2013; Zhao et al., 2014). The microbial structure gets affect with a change in ecosystem functions such as interaction between plants, soil and microorganisms which lead to manipulation in ecological processes (Singh $e t$ al., 2004).

Land management, soil attributes and plant species were important for maintaining the structure and functions of bacterial communities (Nusslein and Tiedje, 1999; Wieland et al., 2001; Steenwerth et al., 2002; Hartman et al., 2008; Lauber et al., 2008; da Jesus et al., 2009 and Balsiak et al., 2014). Our studies indicates that cropping/ presence of plants in soils shows a distinct separation in soil microbial community which was due to that secretion of different quantity and quality of root exudates by plants leads to selection of rhizopheric microbes which in turn results in different microbial communities in soil (Zhang et al., 2013). The presence of various plant species with special functional traits effects the eco-system functioning and improve the intricacy of soil microorganisms by rising the heterogeneity of organic substrates during decomposition of living roots and litter.

Microbial inoculation effect the soil microbial community however its effect was less prominent ef in our studies Plant-soilmicroorganism interaction results in a complex reactions. The inoculations of PGP (Azospirillum brasilense) with maize results in more number of roots in the soil (Dobbelaere et al., 2003). Higher enzymes activity and microbial densities in the rhizospheric zone is due to the inoculation of soils with the beneficial micro-organism (Mawdsley and Burns, 1994; Castro-Sowinski et al., 2007). When rhizobia (Sinorhizobium meliloti) was used as inoculants in field the diversity of bacterial community in the root zone was quantitatively and qualitatively affected. The proteobacteria groups largely get effected by this inoculations which results in the decrease numbers of $\gamma$-proteobacteria whereas the $\alpha$ proteobacteria were increased in numbers (Schwieger and Tebbe, 2000). Different mechanisms of plant nutrient uptake, growth, development and yield of plants were influence by the inoculation of Rhizobium culture. As they are capable to fixed nitrogen, that accelerate the nitrogen-fixing free-living bacteria in soils which in turns results in increase the production of the essential nutrients such as phosphorus and iron for plants. Alterations of soil microbial community by inoculating various beneficial micro-organism is that the inoculants indirectly produce the PGPR compounds like secretion of antibiotic compound which leads to changes in rhizopheric bacterial communities. 
Fig.1 Soil bacterial community at 10 days growth of rice plant

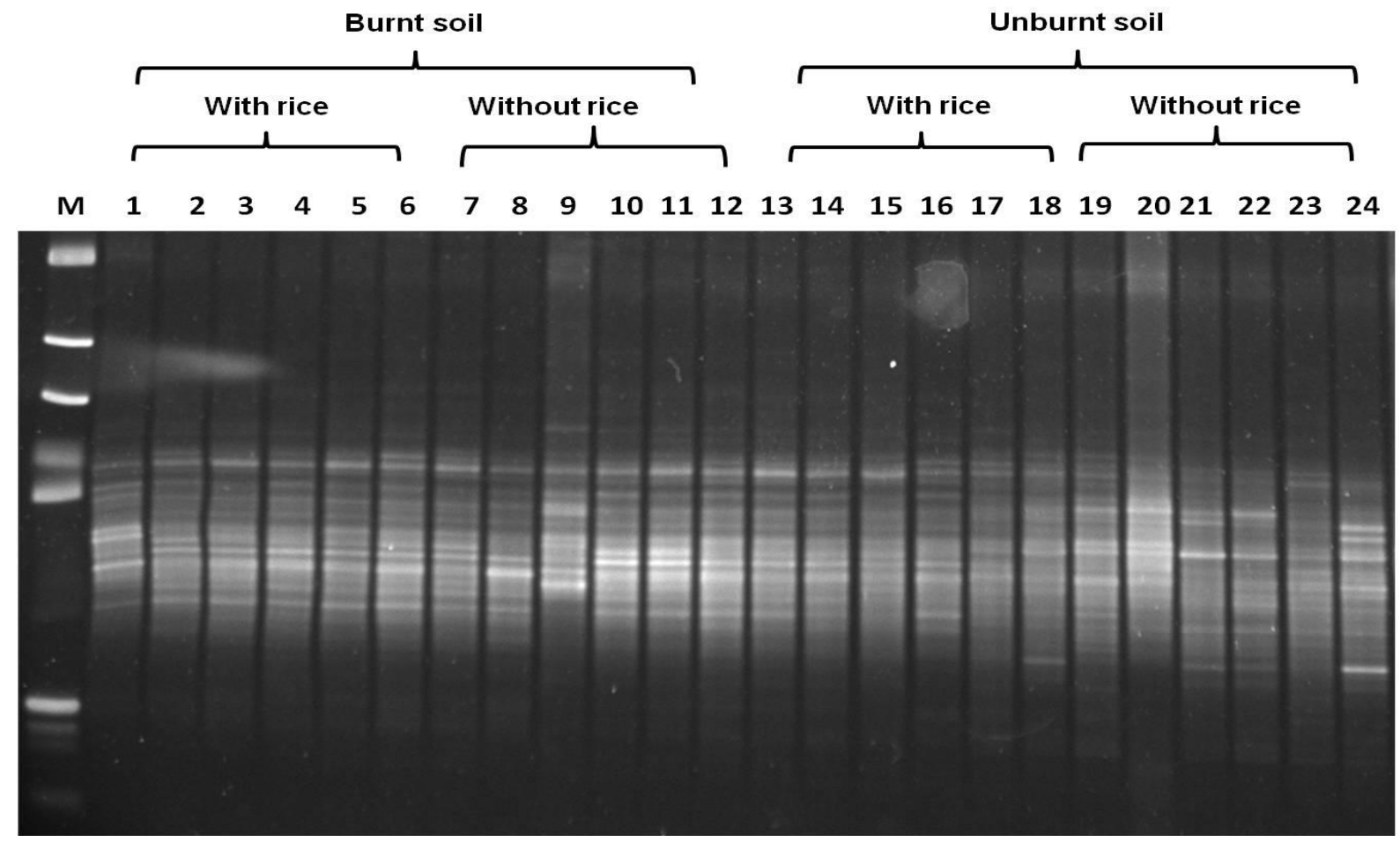

Fig.2 MDS Clustering of bacterial Community at 10 days of rice growth in response to burning, cropping and synthetic microbial inoculants in soils of 5 years Jhum Cycle
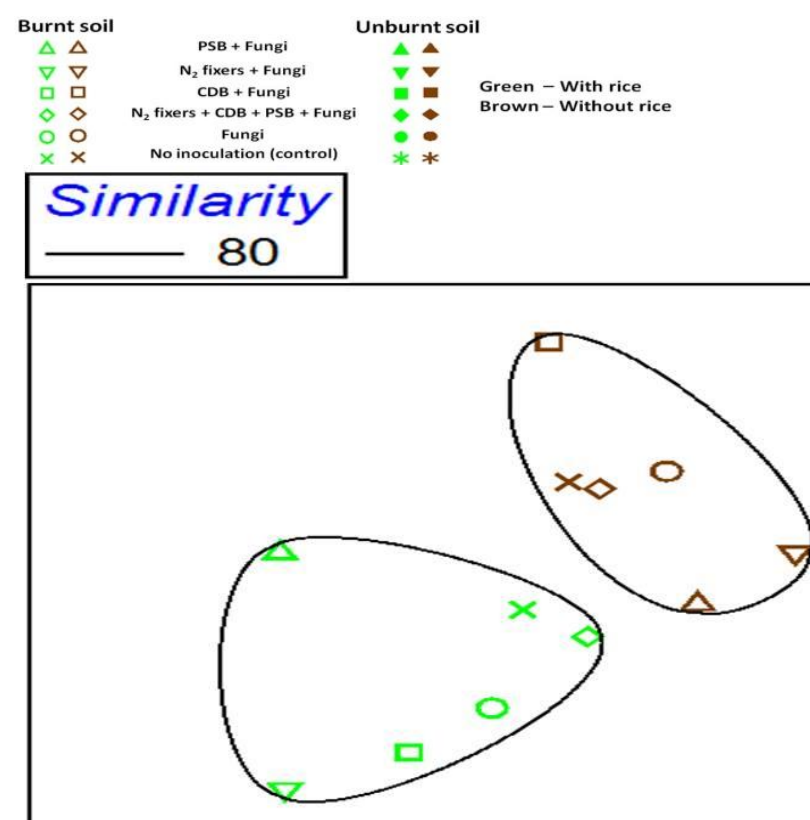
2D Stress: 0.11

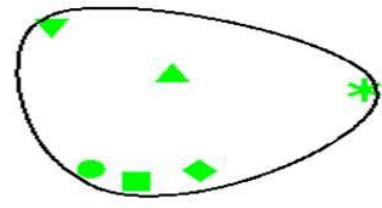


Fig.3 Hierarchical Clustering of bacterial Community at 10 days of rice growth in response to burning, cropping and synthetic microbial inoculants in soils of 5 years Jhum Cycle

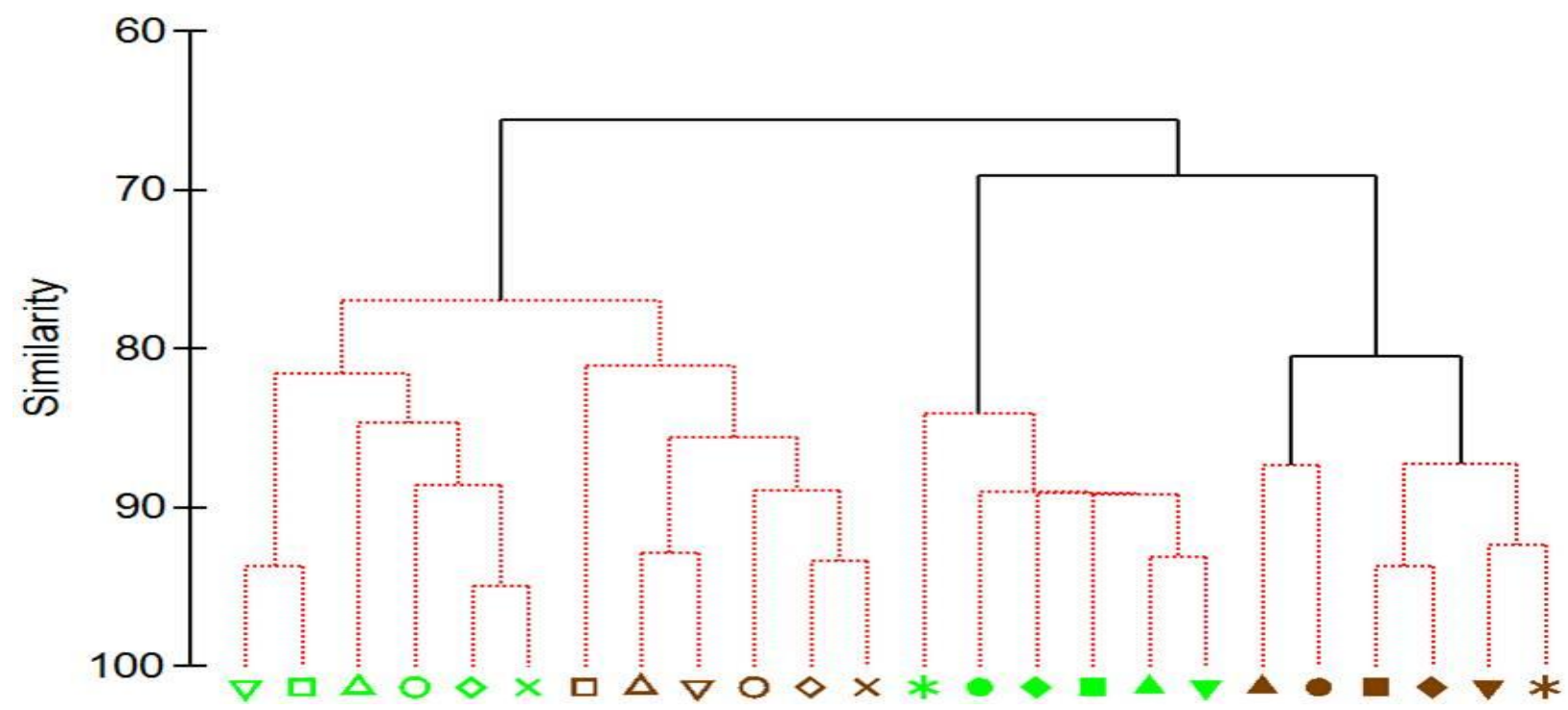

Fig.4 PCR DGGE of Alpha-proteobacterial group at 45 days growth of rice plant

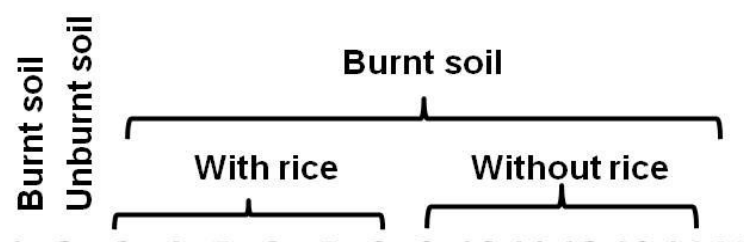

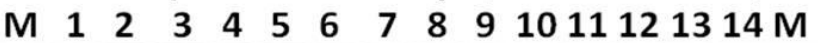
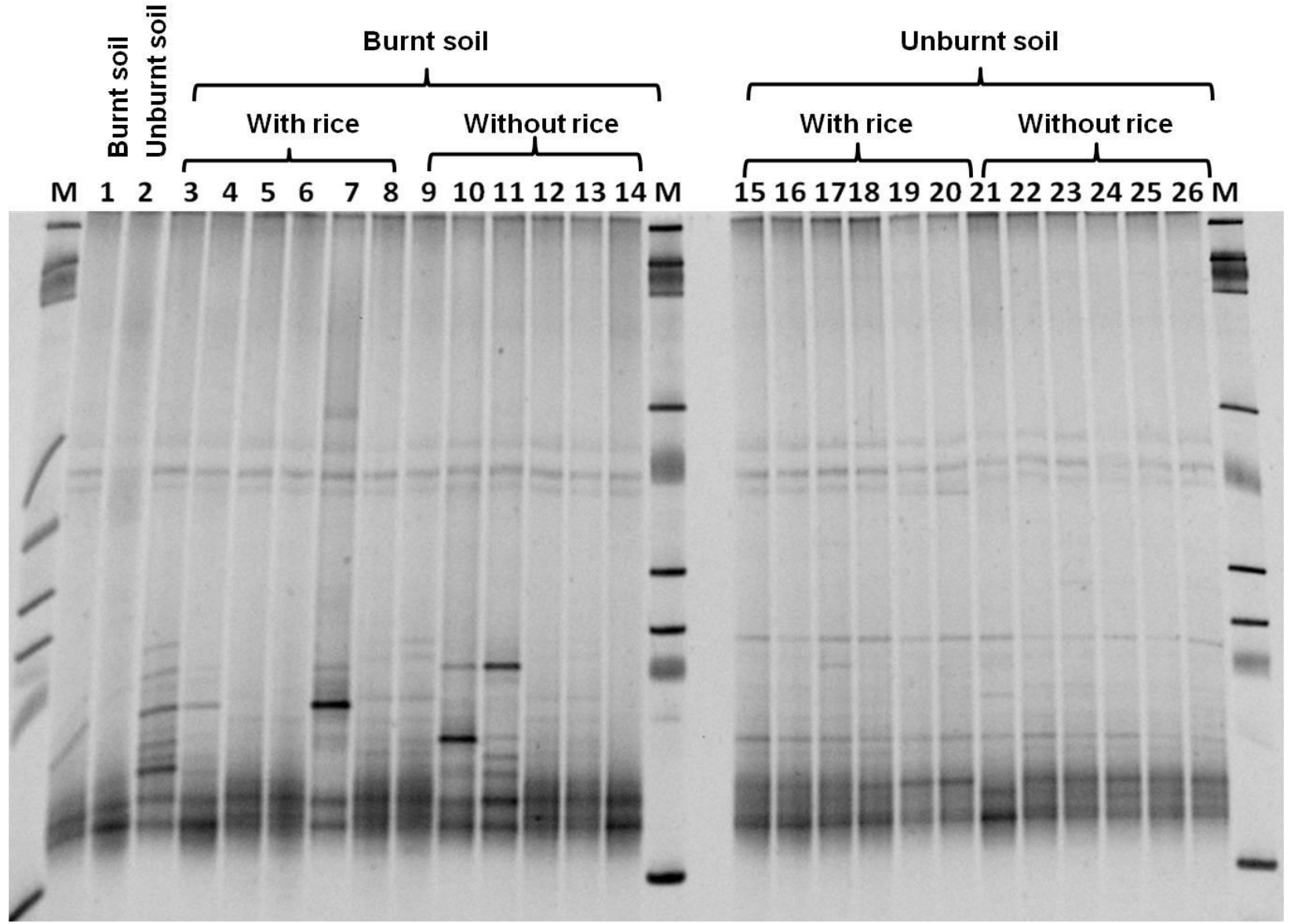
Fig.5 MDS Clustering of alpha-proteobacterial Community at 45 days of rice growth in response to burning, cropping and synthetic microbial inoculants in soils of 5 years Jhum Cycle

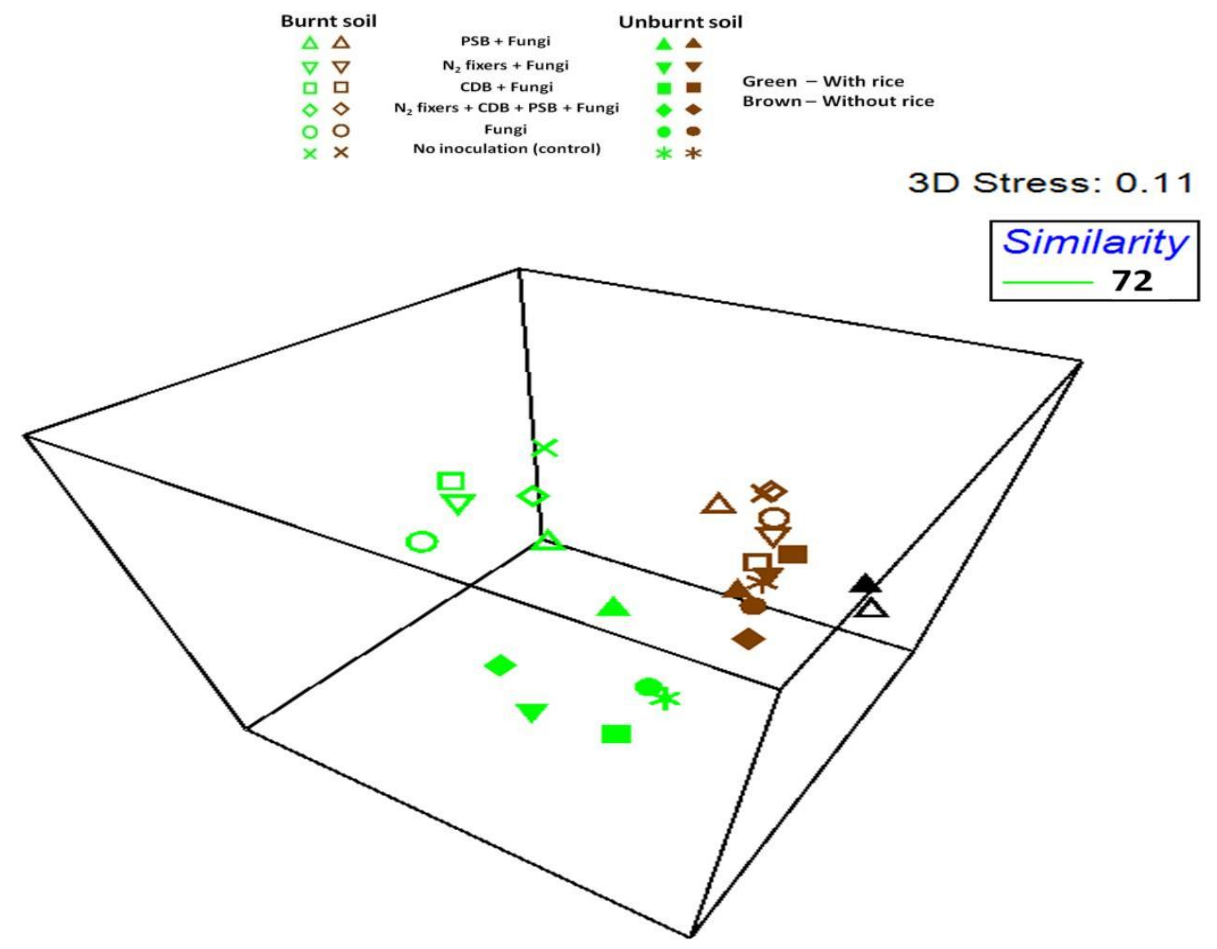

Fig.6 Hierarchical Clustering alpha-proteobacterial Community at 45 days of rice growth in response to burning, cropping and synthetic microbial inoculants in soils of 5 years Jhum Cycle

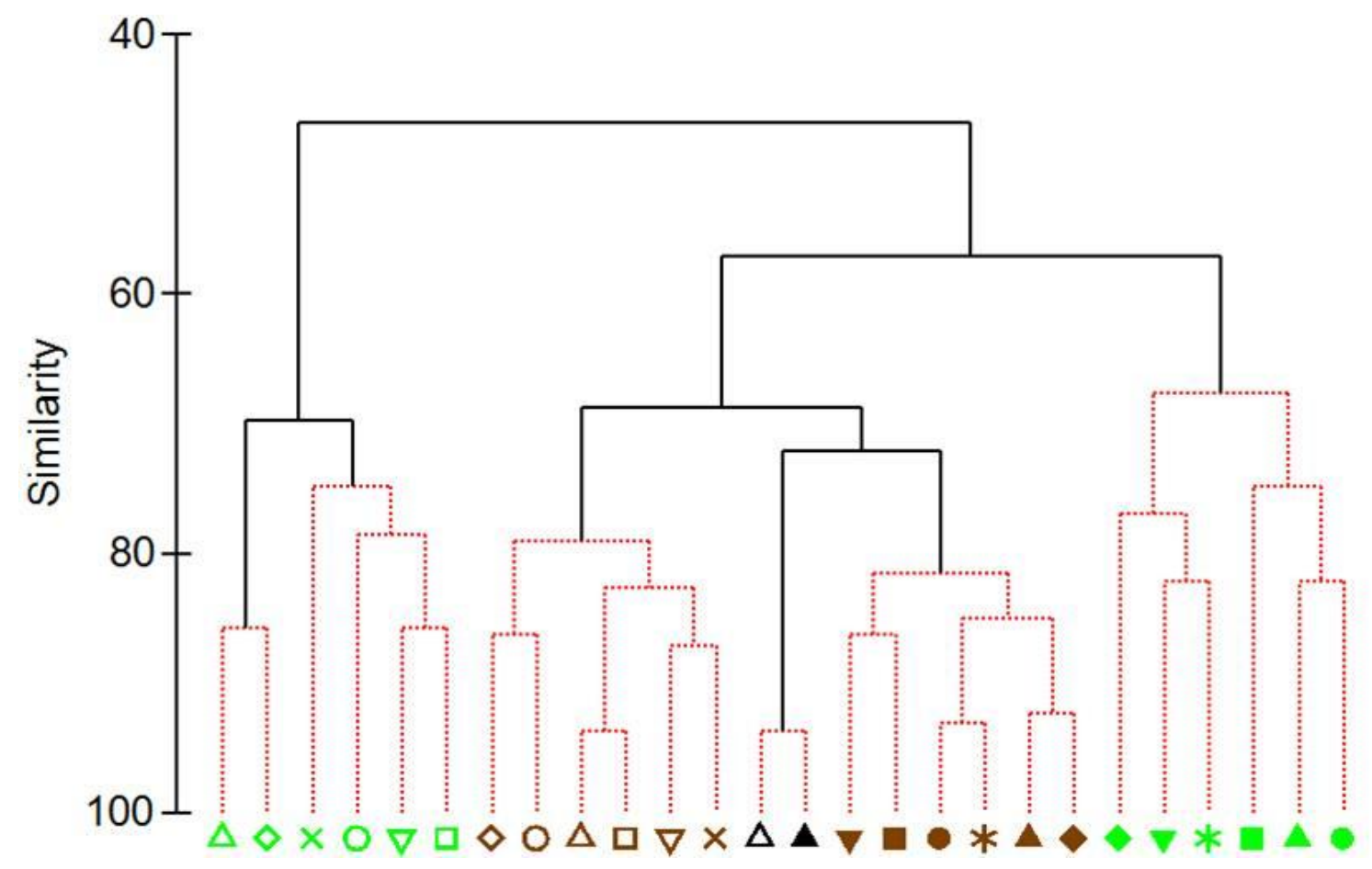


Fig.7 The PCR-DGGE OF Alpha-proteobacterial at 90 days of rice plant growth

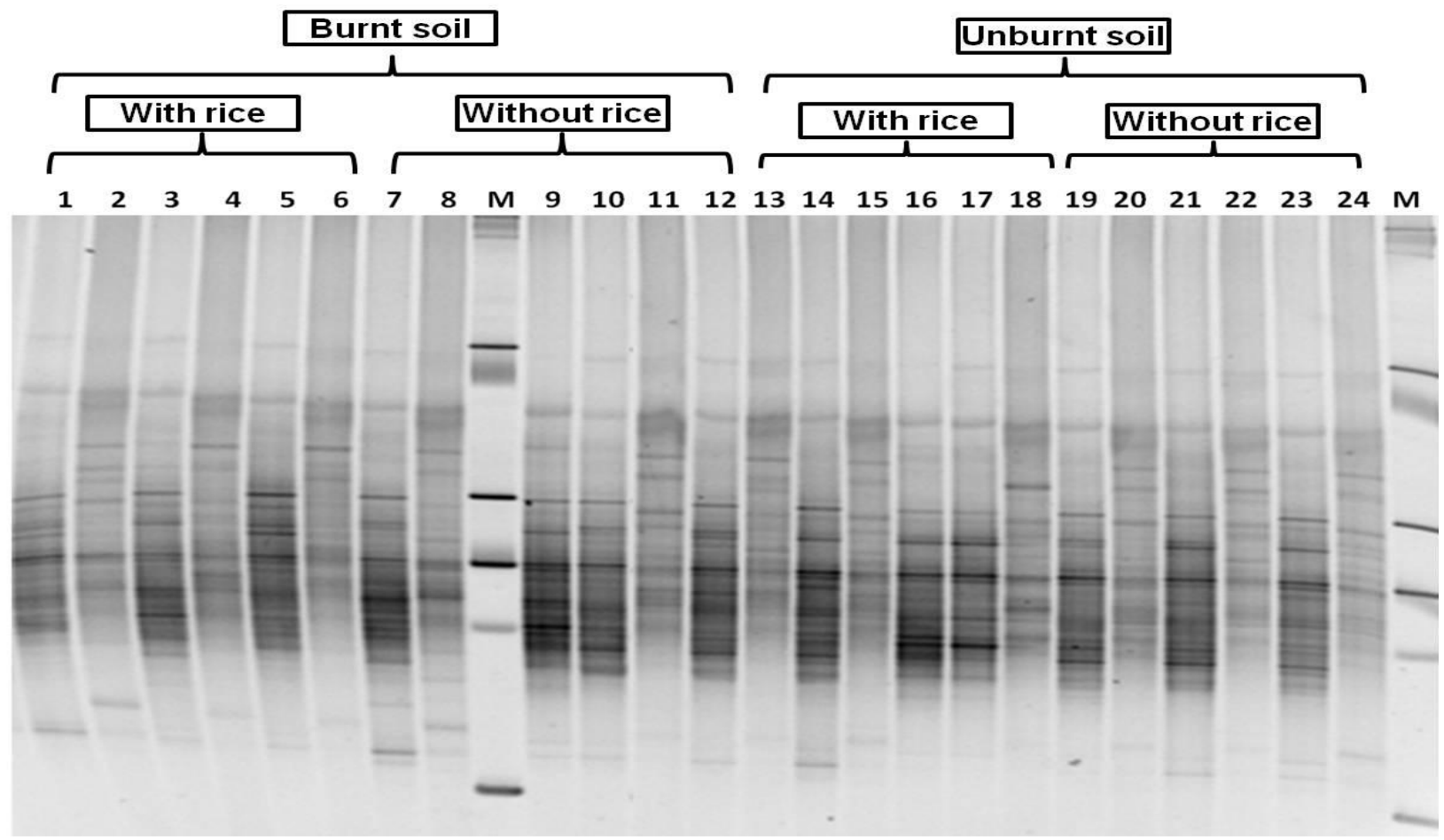

Fig.8 MDS Clustering of alpha-proteobacterial Community at 90 days of rice growth in response to burning, cropping and synthetic microbial inoculants in soils of 5 years Jhum Cycle

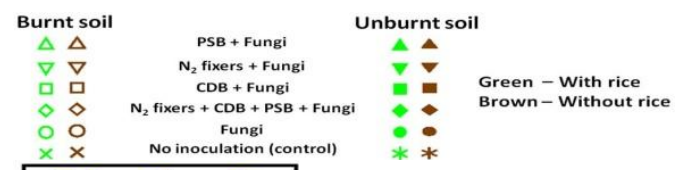

\section{Similarity 58}

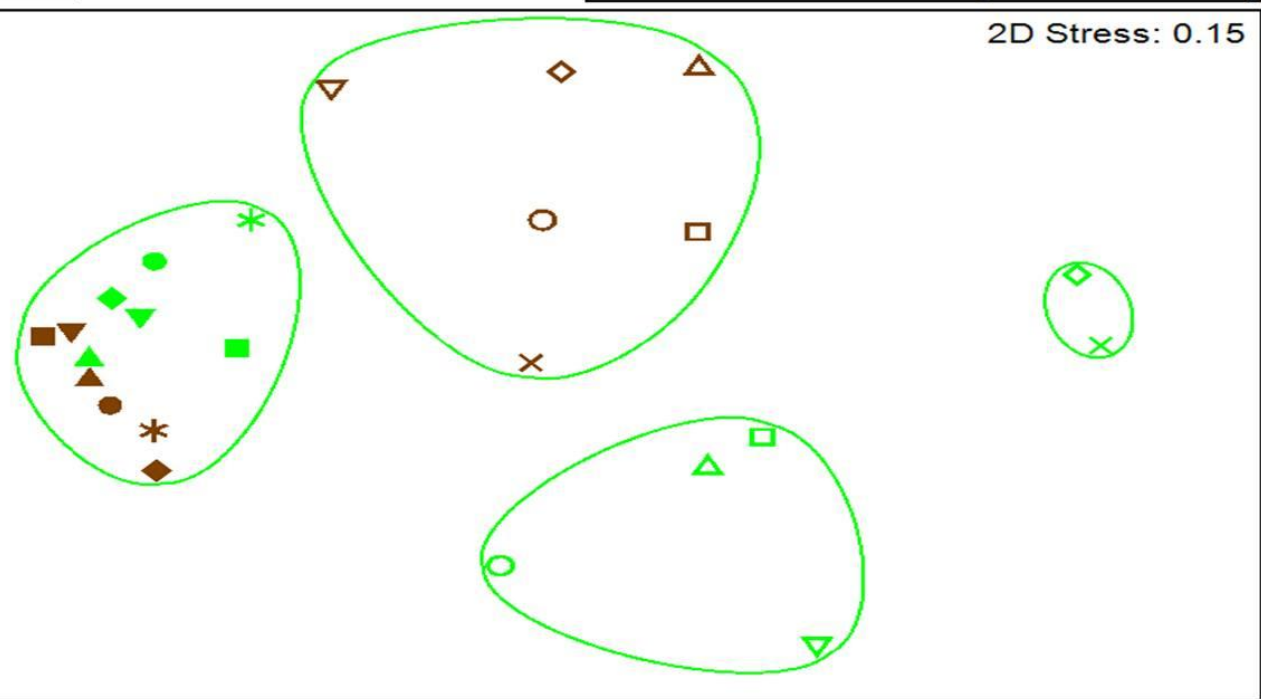


Fig.9 Hierarchical Clustering alpha-proteobacterial Community at 90 days of rice growth in response to burning, cropping and synthetic microbial inoculants in soils of 5 years Jhum Cycle

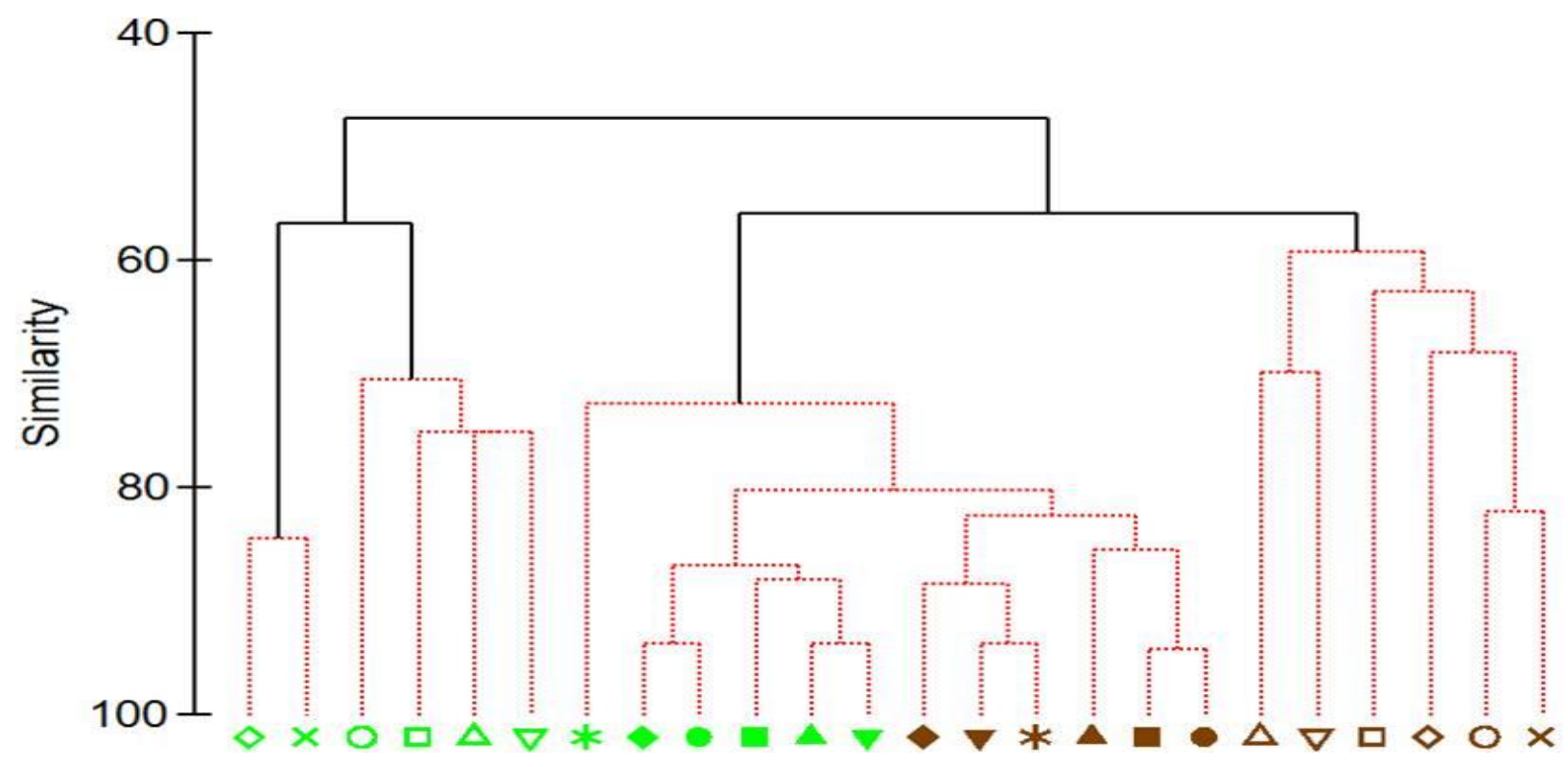

Table.1 Influence of burning on physico-chemical attributes at 5 yrs of jhum cycle soils

\begin{tabular}{|c|c|c|c|c|c|c|c|}
\hline $\begin{array}{c}\mathbf{5} \text { year } \\
\text { Jhum } \\
\text { cycle }\end{array}$ & $\begin{array}{c}\text { BD } \\
\left(\mathbf{M g ~ m}^{-\mathbf{3}}\right)\end{array}$ & $\begin{array}{c}\mathbf{p H} \\
\mathbf{1 : 2 . 5} \\
(\text { soil: water })\end{array}$ & $\begin{array}{c}\mathbf{E C} \\
\left(\boldsymbol{\mu S} \mathbf{~ s}^{-\mathbf{1}}\right)\end{array}$ & $\begin{array}{c}\text { SOC } \\
(\mathbf{\%})\end{array}$ & $\begin{array}{c}\text { Avl N } \\
\left(\mathbf{k g ~ h a}^{-\mathbf{1}}\right)\end{array}$ & $\begin{array}{c}\text { Avl P } \\
\left(\mathbf{k g ~ h a}^{-\mathbf{1}}\right)\end{array}$ & $\begin{array}{c}\text { Avl K } \\
\left(\mathbf{k g ~ h a}^{-\mathbf{1}}\right)\end{array}$ \\
\hline $\begin{array}{c}\text { Unburnt } \\
\text { soil }\end{array}$ & $1.52 \pm 0.07 \mathrm{a}$ & $4.70 \pm 0.12 \mathrm{a}$ & $24.8 \pm 2.7 \mathrm{a}$ & $1.44 \pm 0.04 \mathrm{~b}$ & $273 \pm 23 \mathrm{~b}$ & $6.18 \pm 1.6 \mathrm{a}$ & $220 \pm 10 \mathrm{a}$ \\
\hline Burnt soil & $1.65 \pm 0.08 \mathrm{a}$ & $5.08 \pm 0.16 \mathrm{~b}$ & $33.7 \pm 3.4 \mathrm{~b}$ & $1.18 \pm 0.06 \mathrm{a}$ & $212 \pm 18 \mathrm{a}$ & $9.56 \pm 1.7 \mathrm{~b}$ & $258 \pm 14 \mathrm{~b}$ \\
\hline
\end{tabular}

Spatial and temporal had transient effects on rhizobacterial or fungal population as the root zone was colonized with antibiotic-producing fluorescent pseudomonads, 2,4diacetylphoroglucinol or phenazine colonization of the root zone (De Leij et al., 1995; Girlanda et al., 2001; Naseby \& Lynch, 2001; Bakker et al., 2002; Castro-Sowinski et al., 2007). The trifolitoxin-sensitive bacteria (Alphaproteobacteria) gets reduce in the root zone of bean due to secretions of trifolitoxin by Rhizobium etlidue (Robleto et al., 1998; Trabelsi and Mhamdi, 2013).

Burning of slash biomass on surface soil can altered soil bacterial community composition. The influence of rice crop on composition of soil bacterial community was more prominent in burnt soil than unburnt soil. The clustering behavior of soil bacterial community indicated that the greater influencing factors in shaping community composition is in order of burning $>$ cropping $>$ microbial inoculation. Burning had significant positive influence on rice growth yield. Therefore, it can be concluded that introduction of crop in burn soil along with microbial inoculation may positively influenced soil processes as well as crop growth.

The DGGE fingerprint depicting soil bacterial community at 10 days in jhum rice rhizosphere and bulk soils under burnt and unburnt situations of 5 years jhum cycle as influenced by application of synthetic microbial community composed of $\mathrm{N}_{2}$-fixers 
(NF), phosphate solubilizing bacteria (PSB), cellulose degrading bacteria (CDB), $\mathrm{NF}+\mathrm{PSB}+\mathrm{CDB}$, fungi, and control (no inoculants).

$\mathrm{M}$ - 100 bp marker, lane 1 -PSB+Fungi, lane $2-\mathrm{N}_{2}$-fixers+Fungi, lane 3 -CDB+Fungi, lane $4-\mathrm{NF}+\mathrm{PSB}+\mathrm{CDB}+$ Fungi, lane 5 -Fungi, lane 6 -Control(no inoculation) lane 7 . $\mathrm{PSB}+$ Fungi, lane $8-\mathrm{N}_{2}$-fixers+Fungi, lane 9 $\mathrm{CDB}+$ Fungi, lane $10-\mathrm{NF}+\mathrm{PSB}+\mathrm{CDB}+$ Fungi, lane 11 -Fungi, lane 12 -Control (no inoculation) lane - 13 PSB+Fungi, lane 14 $\mathrm{N}_{2}$-fixers+Fungi, lane $15-\mathrm{CDB}+\mathrm{Fungi}$, lane $16-\mathrm{NF}+\mathrm{PSB}+\mathrm{CDB}+$ fungi, lane 17- Fungi, lane 18 -Control (no inoculation), lane 19 $\mathrm{PSB}+$ Fungi, lane $20-\mathrm{N}_{2}$-fixers+Fungi, lane $21-\mathrm{CDB}+$ Fungi, lane $-22 \mathrm{NF}+\mathrm{PSB}+\mathrm{CDB}$ + Fungi, lane 23 - Fungi, lane 24 - Control(no inoculation)

Lane 1-6 Burnt with rice, Lane 7-12 Burnt without rice, Lane 13-18 Unburnt with rice, Lane 19-24 Unburnt without rice

The DGGE fingerprint depicting alphaproteobacterial community at 45 days in jhum rice rhizosphere and bulk soils under burnt and unburnt situations of 5 years jhum cycle as influenced by application of synthetic microbial community composed of $\mathrm{N}_{2}$-fixers (NF), phosphate solubilizing bacteria (PSB), cellulose degrading bacteria (CDB), $\mathrm{NF}+\mathrm{PSB}+\mathrm{CDB}$, fungi, and control (no inoculants).

M - 100 bp marker, lane 1 -Burnt at 0 days, lane 2 -unburnt at 0 days, lane 3 -PSB+Fungi, lane $4-\mathrm{N}_{2}$-fixers+Fungi, lane 5 -CDB+Fungi, lane $6-\mathrm{NF}+\mathrm{PSB}+\mathrm{CDB}+$ Fungi, lane 7 -Fungi, lane 8 -Control(no inoculation) lane 9 $\mathrm{PSB}+\mathrm{Fungi}$, lane $10-\mathrm{N}_{2}$-fixers+Fungi, lane $11-\mathrm{CDB}+$ Fungi, lane $12-\mathrm{NF}+\mathrm{PSB}+\mathrm{CDB}$ + Fungi, lane 13 -Fungi, lane 14 -Control (no inoculation) lane 15 -PSB+Fungi, lane 16 $\mathrm{N}_{2}$-fixers+Fungi, lane $17-\mathrm{CDB}+$ Fungi, lane
18 -NF+PSB+CDB +fungi, lane 19 -Fungi, lane 20 -Control (no inoculation), lane 21 $\mathrm{PSB}+$ Fungi, lane $22-\mathrm{N}_{2}$-fixers+Fungi, lane 23 -CDB+Fungi, lane $24-\mathrm{NF}+\mathrm{PSB}+\mathrm{CDB}$ +Fungi, lane 25- Fungi, lane 26 -Control(no inoculation). Lane 3-8 Burnt with rice, Lane 9-14 Burnt without rice, Lane 15-20 Unburnt with rice, Lane 21-26 Unburnt without rice

The DGGE fingerprint depicting alphaproteobacterial community at 90 days in jhum rice rhizosphere and bulk soils under burnt and unburnt situations of 5 years jhum cycle as influenced by application of synthetic microbial community composed of $\mathrm{N}_{2}$-fixers (NF), phosphate solubilizing bacteria (PSB), cellulose degrading bacteria (CDB), $\mathrm{NF}+\mathrm{PSB}+\mathrm{CDB}$, fungi, and control (no inoculants).

$\mathrm{M}$ - 100 bp marker, lane 1 -PSB+Fungi, lane $2-\mathrm{N}_{2}$-fixers+Fungi, lane $3-\mathrm{CDB}+$ Fungi, lane $4-\mathrm{NF}+\mathrm{PSB}+\mathrm{CDB}+$ Fungi, lane 5 -Fungi, lane 6 -Control (no inoculation) lane 7 PSB+Fungi, lane $8-\mathrm{N}_{2}$-fixers+Fungi, lane 9 $\mathrm{CDB}+$ Fungi, lane $10-\mathrm{NF}+\mathrm{PSB}+\mathrm{CDB}+$ Fungi, lane 11 -Fungi, lane 12 -Control (no inoculation) lane - 13 PSB+Fungi, lane 14 $\mathrm{N}_{2}$-fixers+Fungi, lane $15-\mathrm{CDB}+$ Fungi, lane $16-\mathrm{NF}+\mathrm{PSB}+\mathrm{CDB}+$ fungi, lane 17- Fungi, lane 18 -Control (no inoculation), lane 19 $\mathrm{PSB}+$ Fungi, lane $20-\mathrm{N}_{2}$-fixers+Fungi, lane $21-\mathrm{CDB}+$ Fungi, lane $-22 \mathrm{NF}+\mathrm{PSB}+\mathrm{CDB}$ + Fungi, lane 23 - Fungi, lane 24 - Control (no inoculation).

Lane 1-6 Burnt with rice, Lane 7-12 Burnt without rice, Lane 13-18 Unburnt with rice, Lane 19-24 Unburnt without rice.

\section{References}

Alguacil, M.M., Torrecillas, E., GarcíaOrenes, F. and Roldán, A. 2014. Changes in the composition and diversity of AMF communities 
mediated by management practices in a Mediterranean soil are related with increases in soil biological activity. Soil Biol. and Biochem, 76: 34-44.

Bakker, P.A.H.M., Glandorf, D.C.M., Viebahn, M., Ouwens, T.W.M., Smit, E., Leeflang, P., Wernars, K., Thomashow, L.S., Thomas-Oates, J.E., and van Loon, L.C. 2002. Effects of Pseudomonas putida modified to produce phenazine-1-carboxylic acid and 2, 4-diacetylphloroglucinol on the microflora of field grown wheat. Antonie van Leeuwenhoek 81:617-624.

Bardgett, R.D. 2008. The Biology of Soil: A Community and Ecosystem Approach, Oxford University Press.

Blasiak, L.C. Alex W., et al., 2014. Bacterial Communities in Malagasy Soils with Differing Levels of Disturbance Affecting Botanical Diversity. PLOS ONE, 9: e85097

Da Jesus, E.C., Marsh, T.L., Tiedje, J.M. and de Moreira F.M.S. 2009. Changes in land use alter the structure of bacterial communities in western Amazon soils. The ISME J., 3:1004-1011.

De Leij, F.A.A.M., Sutton, E.J., Whipps, J.M., Fenlon, J.S. and Lynch, J.M. 1995. Impact of field release of genetically modified Pseudomonas fluorescens on indigenous microbial populations of wheat. Appl Environ Microbiol 61: 3443-3453.

Dobbelaere, S., Vanderleyden, J. and Okon, Y. 2003. Plant growthpromoting effects of diazotrophs in the rhizosphere. CRC Crit Rev Plant Sci 22: 107-149.

Girlanda, M., Perotto, S., Moenne -Loccoz, Y., Bergero, R., Lazzari, A., Defago, G., Bonfante, P., and Luppi, A.M. 2001. Impact of biocontrol Pseudomonas fluorescens $\mathrm{CHAO}$ and a genetically modified derivative on the diversity of culturable fungi in the cucumber rhizosphere. Appl Environ Microbiol
67: 1851-1864.

Girvan, M.S., Campbell, C.D., Kilham, K., Prosser, J.I. and Glover, L.A. 2005. Bacterial diversity promotes community stability and functional resilience after perturbation. Environ Microbiol 7:301313.

Hamman, S.T., Burke, I.C. and Stromberger, M.E. 2007. Relationships between microbial community structure and soil environmental conditions in a recently burned system. Soil Biol. Biochem., 39: 1703-1711. 133.

Hartman, W.H., Richardson, C.J., Vilgalys, R., and Bruland, G.L. 2008. Environmental and anthropogenic controls over bacterial communities in wetland soils. Proc. Natl. Acd. Sc. USA., 105:17842-17847.

Hoorman, J.J. 2011. The Role of Soil Fungus. Fact sheet: Agriculture and Natural Resource, The Ohio State University. $S A G-14-11$.

Köhl, L., Oehl, F., van der Heijden, M.G.A. 2014. Agricultural practices indirectly influence plant productivity and ecosystem services through effects on soil biota. Ecol. Appl., 24: 1842-1853.

Lane D. J. 1991. 16S/23S rRNA sequencing. In: E. Stackebrandt and M. Goodfellow (ed.), Nucleic acid technology in bacterial systematics. John Wiley and Sons, New York, N.Y. Pp. 115-175.

Lauber, C.L., Strickland, M.S., Bradford, M.A. and Fierer, N. 2008. The influence of soil properties on the structure of bacterial and fungal communities across land-use types. Soil Biol Biochem., 40:2407-2415.

Lavelle, P. 1997. Faunal activities and soil processes: Adaptive strategies that determine ecosystem function. In: Beggan, M. and Fitter, A.H. (eds) Advances In Ecological Research, Elsevier Limited, Netherland, 27: 93132. 
Liliensiek, K.A., Thakuria, D. and Clipson, N. 2012. Influences of Plant Species Composition. Fertilisation and Lolium perenne Ingression on Soil Microbial Community Structure in Three Irish Grasslands. Microb Ecol., 63: 509-521.

Mawdsley, J.L. and Burns, R.G. 1994. Inoculation of plants with a Flavobacterium species results in altered rhizosphere enzyme activities. Soil Biol Biochem 26: 871-882.

Naseby, D.C. and Lynch, J.M. 2001. Effect of 2, 4- diacetylphloroglucinol producing, overproducing, and nonproducing Pseudomonas fluorescens F113 in the rhizosphere of pea. Microb Ecol 42: 193-200.

Nusslein, K., Tiedje, J.M. (1999) Soil bacterial community shift correlated with change from forest to pasture vegetation in a tropical soil. Appl. Environ. Microb. 65, 3622-3626.

Page, A.L., Miller, R.L. and Keeny, D.R. 1982. Methods of soil analysis. Part-2 chemical and microbiological properties, 2nd edition, Agronomy Monograph, 9: 961-1010, ASA, SSSA, CSSA, Madison.

Robleto, E.A., Borneman, J. and Triplett, E. W. 1998. Effects of bacterial antibiotic production on rhizosphere microbial communities from a cultureindependent perspective. Appl Environ Microbiol 64: 5020-5022.

Schwieger, F. and. Tebbe, C. C. 2000. "Effect of field inoculation with Sinorhizobium meliloti L33 on the composition of bacterial communities in rhizospheres of a target plant (Medicago sativa) and a non-target plant (Chenopodium album)-linking of $16 \mathrm{~S}$ rRNA genebased single-strand conformation polymorphism community profiles to the diversity of cultivated bacteria," Appl. Environ. Microbiol, 66: 35563565.
Singh, B.K., Millard, P., Whiteley, A.S., Murrell, J.C. 2004. Unravelling rhizosphere-microbial interactions: opportunities and limitations. Trend Microbiol. 12, 386-393.

Sowinski, S, C., Herschkovitz, Y., 1, Okon, Y. and Jurkevitch, E. 2007. Effects of inoculation with plant growthpromoting rhizobacteria on resident rhizosphere microorganisms. FEMS Microbiol Lett., 276:1-11.

Stach J.E.M., Bathe S., Clapp J.P. and Burns R.G. 2001. PCR-SSCP comparison of $16 \mathrm{~S}$ rDNA sequence diversity in soil DNA obtained using different isolation and purification methods. FEMS Microb. Ecol., 36: 139-151.

Steenwerth, K.L., Jackson, L.E., Calderon, F.J., Stromberg, M.R., and Sow K.M. 2002. Soil microbial community composition and land use history in cultivated and grassland ecosystems of coastal California. Soil Biol. Biochem., 34: 1599-1611.

Subba Rao N.S. 1999. Soil Microbiology $\left(4^{\text {th }}\right.$ Edition, Soil Microorganisms and Plant Growth), Oxford and IBH Publishing Co. Pvt. Ltd., New Delhi.

Suleiman, A.K.A., Manoelib, L., Boldoa, J.T., Pereirac, M.G. and Roescha, L.F.W. 2013. Shifts in soil bacterial community after eight years of land-use change. Syst. and Appl. Microb., 36: 137-144.

Thakuria D., Schmidt O., MacSuirtain M., Egan D. and Doohan F.M. 2008. Importance of DNA quality in comparative soil microbial community structure analyses. Soil Biol. Biochem., 40:1390-1403.

Trabelsi, D., and Mhamdi R. 2013. Microbial Inoculants and Their Impact on Soil Microbial Communities: A Review. BioMed Research International, 2013; 1-11

Wieland, G., Neumann, R., and Backhaus, H. 2001. Variation of microbial 
communities in soil, rhizosphere, and rhizoplane in response to crop species, soil type and crop development. Appl. Environ. Microbiol, 67:5849-5854.

Wolfe, B.E. and Kilrionomos, J.N. 2005. Breaking new ground: Soil communities and exotic plant invasion. Biosci, 55: 477-487.

Xiang, X.J., Shi, Y.U., Yang, J., Kong, J., Lin, X., Zhang and Zeng J. 2014. Rapid recovery of soil bacterial communities after wildfire in a Chinese boreal forest.
Sci. Rep., 4, 3829.

Zhang, H., Song, X., Wangd, C., Liu, H., Zhang, J., Li, Y., Li, G., Yang, D., Zhao, X. 2013. The effects of different vegetation restoration patterns on soil bacterial diversity for sandy land in Hulunbeier Acta Ecologica Sinica, 33: 211-216.

Zhou, J.Z., Bruns, M.A., Tiedje, J.M. 1996. DNA recovery from soils of diverse composition. Appl. Environ. Microbiol, $62: 316-322$.

\section{How to cite this article:}

Carolyn Zothansiami. 2019. Impact of Burning, Cropping and Microbial Inoculation on Soil Alpha-Proteobacterial Community Composition in Shifting Cultivation Cycle. Int.J.Curr.Microbiol.App.Sci. 8(07): 287-301. doi: https://doi.org/10.20546/ijcmas.2019.807.036 